Article

\title{
Automated Synthesis of Fluorine-18 Labeled CXCR4 Ligand via the Conjugation with Nicotinic Acid $N$-Hydroxysuccinimide Ester (6-[ $\left.\left.{ }^{18} \mathrm{~F}\right] \mathrm{SFPy}\right)$
}

\author{
Falguni Basuli ${ }^{1, *}$, Xiang Zhang ${ }^{1}$, Tim E. Phelps ${ }^{2}$, Elaine M. Jagoda ${ }^{2}$, Peter L. Choyke ${ }^{2}$ \\ and Rolf E. Swenson ${ }^{1}$ \\ 1 Chemistry and Synthesis Center, National Heart, Lung, and Blood Institute, National Institutes of Health, \\ Rockville, MD 20892, USA; xiang.zhang2@nih.gov (X.Z.); rolf.swenson@nih.gov (R.E.S.) \\ 2 Molecular Imaging Program, National Cancer Institute, National Institutes of Health, \\ Bethesda, MD 20892, USA; tim.phelps@nih.gov (T.E.P.); ejagoda@mail.nih.gov (E.M.J.); \\ pchoyke@mail.nih.gov (P.L.C.) \\ * Correspondence: bhattacharyyaf@mail.nih.gov
}

Received: 1 August 2020; Accepted: 25 August 2020; Published: 27 August 2020

check for updates

\begin{abstract}
The C-X-C motif chemokine receptor 4 (CXCR4) is a seven-transmembrane G protein-coupled receptor that is overexpressed in numerous diseases, particularly in various cancers and is a powerful chemokine, attracting cells to the bone marrow niche. Therefore, CXCR4 is an attractive target for imaging and therapeutic purposes. The goal of this study is to develop an efficient, reproducible, and straightforward method to prepare a fluorine-18 labeled CXCR4 ligand. 6- $\left[{ }^{18} \mathrm{~F}\right]$ Fluoronicotinic acid-2,3,5,6-tetrafluorophenyl ester (6- $\left.\left[{ }^{18} \mathrm{~F}\right] \mathrm{FPy}-\mathrm{TFP}\right)$ and nicotinic acid N-hydroxysuccinimide ester $\left(6-\left[{ }^{18} \mathrm{~F}\right] \mathrm{SFPy}\right)$ have been prepared using 'fluorination on the Sep-Pak' method. Conjugation of $6-\left[{ }^{18} \mathrm{~F}\right] \mathrm{SFPy}$ or $6-\left[{ }^{18} \mathrm{~F}\right] \mathrm{FPy}$-TFP with the alpha-amino group at the $\mathrm{N}$ terminus of the protected T140 precursor followed by deprotection, yielded the final product $6-\left[{ }^{18} \mathrm{~F}\right] \mathrm{FPy}-\mathrm{T} 140$. The overall radiochemical yields were $6-17 \%(n=15$, decay-corrected $)$ in a 90 -min radiolabeling time with a radiochemical purity $>99 \% .6-\left[{ }^{18} \mathrm{~F}\right] \mathrm{FPy}-\mathrm{T} 140$ exhibited high specific binding and nanomolar affinity for CXCR4 in vitro, indicating that the biological activity of the peptide was preserved. For the first time, $\left[{ }^{18} \mathrm{~F}\right] \mathrm{SFPy}$ has been prepared using 'fluorination on the Sep-Pak' method that allows rapid automated synthesis of 6-[ $\left.{ }^{18} \mathrm{~F}\right] \mathrm{FPy}-\mathrm{T} 140$. In addition to increased synthetic efficiency, this construct binds with CXCR4 in high affinity and may have potential as an in vivo positron emission tomography (PET) imaging agent. This radiosynthesis method should encourage wider use of this PET agent to quantify CXCR4 in both research and clinical settings.
\end{abstract}

Keywords: fluorine-18; fluorination on the Sep-Pak; SFPy; CXCR4; T140

\section{Introduction}

Chemokine receptors (CRs) are seven-transmembrane $\mathrm{G}$ protein-coupled receptors that trigger intracellular signaling and drive cell polarization, adhesion, and migration [1]. The chemokine receptor type 4 (CXCR4) is a distinctive member of the CR family, possessing additional functions during embryonic development, and has been widely studied with the initial discovery that CXCR4 is one of the co-receptors for human immunodeficiency virus (HIV) entry into target cells [2-5]. CXCR4 is expressed on most hematopoietic cell types and stem cells. The structure of CXCR4 consists of 352 amino acid residues comprising an N-terminal domain, seven TM domains, three extracellular loops (ECL), three intracellular loops (ICL), and a C-terminal domain [6]. This chemokine receptor is overexpressed in a variety of cancers including kidney, lung, brain, prostate, breast, pancreas, ovarian, and melanomas [7-9]. The natural ligand for CXCR4, CXCL12, also known as a stromal cell-derived 
factor (SDF)-1, is a 67-residue large peptide that is expressed and secreted in different organs such as the liver, lung, kidney, brain, and bone marrow $[3,4,10,11]$. The CXCL12/CXCR4 axis plays an important role in normal cell migration, inflammation, and immune surveillance. In addition, this axis is required for embryonic development and certain physiological functions including hematopoiesis, organogenesis, and vascularization [12]. Dysregulation of CXCL12/CXCR4 signaling is associated with numerous pathological conditions, including various types of cancers, chronic inflammatory diseases, cardiovascular diseases, and immunodeficiencies [13-15]. Therefore, CXCR4 is an attractive target for imaging cancerous lesions and their microenvironment which may have clinical applications towards diagnosis and patient selection for not only targeted therapeutics but immunotherapies as well [16-20].

Numerous truncated peptide analogs that mimic the function of CXCL12 have been reported [17,21]. Tamamura et al. described the synthesis of novel 14-amino acid peptide inhibitors (T134, T140) based on the structure of their previously reported 18-amino acid peptide, T22, for inhibitory activity against HIV-1 entry [22,23]. These peptides demonstrated high anti-HIV activity with significantly less cytotoxicity when compared to T22. Inhibitory activity has also been detected against a variety of cancer types causing a reduction in metastasis and progression [24-29]. The same group observed enhancement of anti-HIV activity by introducing a 4-fluorobenzoyl group on a T140-based pharmacophore and developed 4-fluorobenzoyl-TN14003 (4-FBz-T140, Figure 1) [30]. The fluorine atom of 4-FBz-T140 could be replaced by fluorine- 18 with no change in the structure of the peptide, thereby providing a potential candidate for a CXCR4 PET imaging agent.

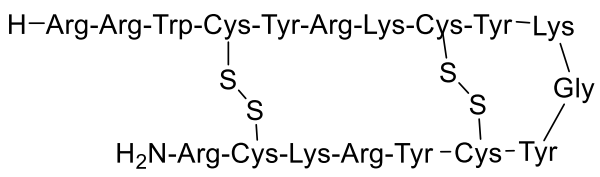

T22

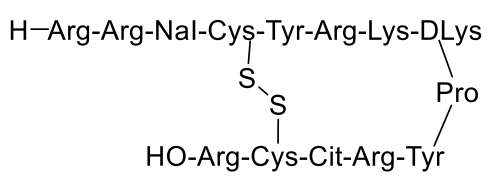

T140

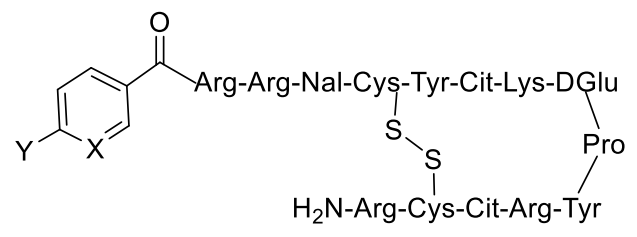

$X=C, Y=F$, TF14013

$X=N, Y=H$, TF14031
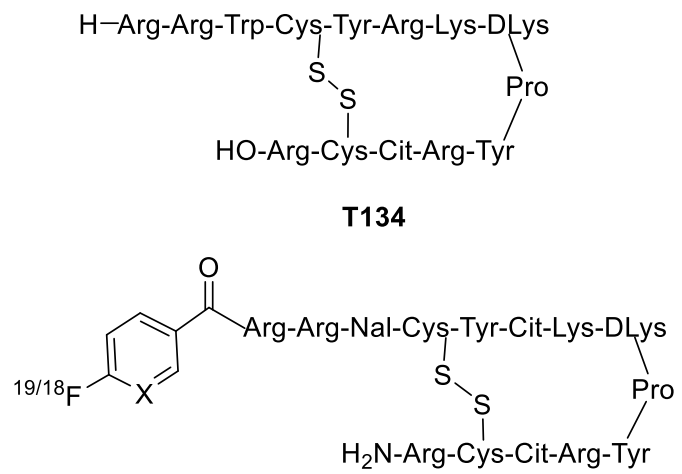

$\mathrm{X}=\mathrm{C},{ }^{19} \mathrm{~F}, 4-\mathrm{FBz}-\mathrm{T} 140 ;{ }^{18} \mathrm{~F}, 4-\left[{ }^{18} \mathrm{~F}\right] \mathrm{FBz}-\mathrm{T} 140$

$\mathrm{X}=\mathrm{N},{ }^{18} \mathrm{~F}, 6-\left[{ }^{18} \mathrm{~F}\right] \mathrm{FPy}-\mathrm{T} 140$ (current study)

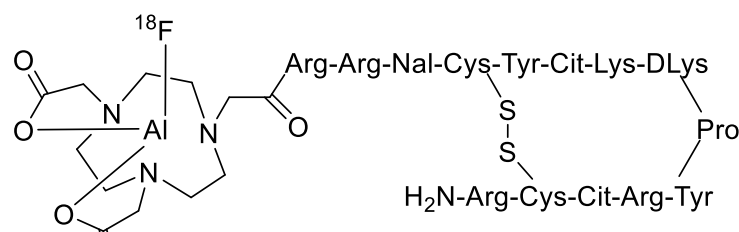

AI $\left[{ }^{18}\right.$ F $]$ NOTA-T140

Figure 1. Structures of C-X-C motif chemokine receptor 4 (CXCR4) ligands.

In 2010, Jacobson et al. reported the synthesis of fluorine-18 labeled analog, 4- $\left[{ }^{18} \mathrm{~F}\right]$ fluorobenzoylTN14003 (4- $\left.\left[{ }^{18} \mathrm{~F}\right] \mathrm{FBz}-\mathrm{T} 140\right)$, in four steps using $\left[{ }^{18} \mathrm{~F}\right] \mathrm{SFB}$ from which CXCR4 positive tumors were visualized in a xenograft mouse model at high tumor-to-background ratios [31]. These high tumor-to-background ratios were achieved by blocking the elevated binding of $4-\left[{ }^{18} \mathrm{~F}\right] \mathrm{FBz}-\mathrm{T} 140$ to red blood cells (RBCs) with non-radioactive standard 4-FBz-T140 peptide. However, due to the complex and time-consuming radiolabeling procedure, they developed another analog, (Al[ $\left.{ }^{18} \mathrm{~F}\right]$ NOTA-T140), using the Al-F method [32]. Although the radiolabeling method was significantly simplified with high radiochemical yield and molar activity, the tracer showed high uptake in the liver and kidneys. 
Tamamura et al. developed a pyridyl analog (TF14031) of TF14013, which showed similar anti-HIV activity as that of TF14013 [30]. Therefore, we anticipated that the pyridyl analog of 4- $\left[{ }^{18} \mathrm{~F}\right] \mathrm{FBz}-\mathrm{T} 140$ would retain the potency of the tracer while facilitating an easier and more efficient radiosynthesis method. Herein, the synthesis of $\left[{ }^{18} \mathrm{~F}\right] \mathrm{SFPy}$, a pyridyl analog of $\left[{ }^{18} \mathrm{~F}\right] \mathrm{SFB}$, using the 'fluorination on the Sep-Pak' method and subsequent conjugation of $\left[{ }^{18} \mathrm{~F}\right] \mathrm{SFPy}$ with the peptide precursor to produce the novel PET tracer, $6-\left[{ }^{18} \mathrm{~F}\right] \mathrm{FPy}-\mathrm{T} 140$, is reported. The simplicity of this labeling procedure allows us to successfully develop an automated synthesis method.

\section{Result and Discussion}

\subsection{Chemistry and Radiochemistry}

In a patent application, Siebeneicher et al. first reported the synthesis of $6-\left[{ }^{18} \mathrm{~F}\right] \mathrm{SFPy}$ in a three-step reaction from fluorination of ethyl 6-chloronicotinate followed by hydrolysis and esterification [33]. Recently, Richard et al. reported a one-step synthesis of 6- $\left[{ }^{18} \mathrm{~F}\right] \mathrm{SFPy}$ by reacting ammonium precursors of NHS ester with [ $\left.{ }^{18} \mathrm{~F}\right] \mathrm{KF} / \mathrm{K}_{2} \mathrm{CO}_{3} / \mathrm{K}_{222}$ either at room temperature or at $40{ }^{\circ} \mathrm{C}$ [34]. However, in this report, the low radiochemical yields for NHS and TFP esters were due to the instability of these esters under the radiolabeling conditions. Our recently developed 'fluorination on the Sep-Pak' method, which does not require elevated temperatures or the addition of a base, was therefore used to prepare $6-\left[{ }^{18} \mathrm{~F}\right] \mathrm{SFPy}[35,36]$. The precursor was prepared in three steps starting with commercially available 6-chloro nicotinic acid. The formation of NHS ester (1, Scheme 1) was achieved according to the literature method [37]. The substitution of chloride (1) with trimethylamine gas to prepare trimethylammonium salt (2) was unsuccessful, as reported [34,38]. Alternatively, compound $\mathbf{2}$ was successfully prepared in high yield $(\sim 80 \%)$ by using $1 \mathrm{M}$ trimethylamine solution in THF. Finally, anion exchange with trimethylsilyl triflate (TMSOTf) produced the desired triflate salt of the trimethylammonium precursor (3, Scheme 1).<smiles>CC(F)(F)[C@H]1CC(=O)N(OC(=O)c2ccc(Cl)nc2)C1=O</smiles>

1

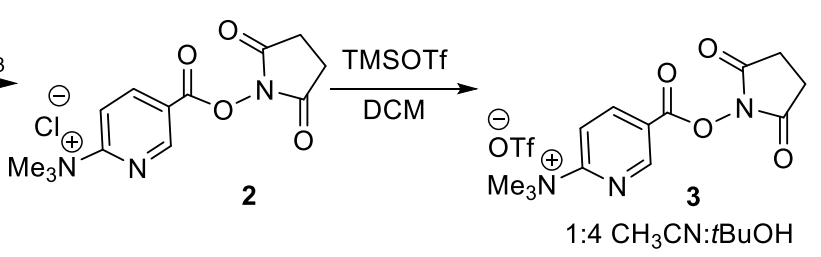

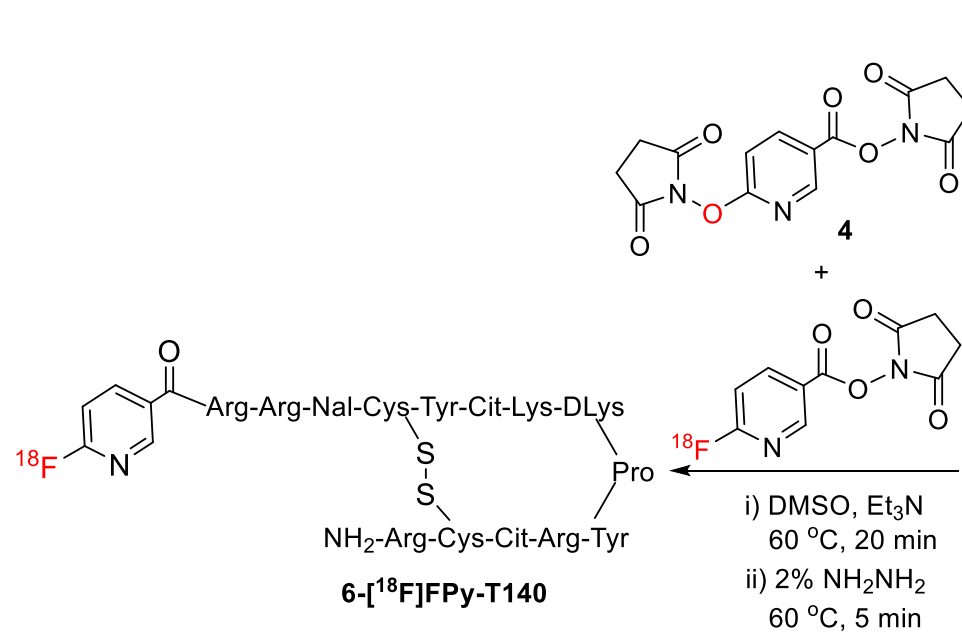

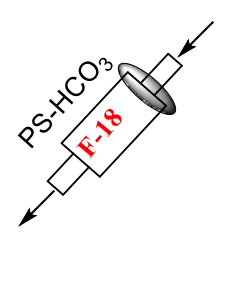

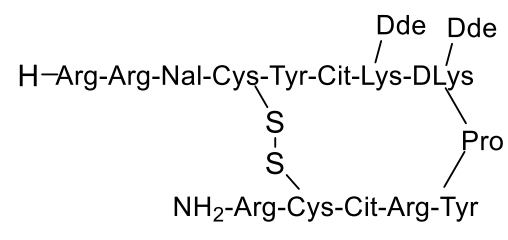
5

Scheme 1. Preparation of $\left[{ }^{18} \mathrm{~F}\right] \mathrm{SFPy}$ by Sep-Pak fluorination method and conjugation with T140. 
To test the efficacy of the 'fluorination on the Sep-Pak' method, $10 \mathrm{mg}$ of precursor (3) in $500 \mathrm{uL}$ of 1:4 acetonitrile, $t$-butanol solution was passed through the cartridge (PS- $\left.\mathrm{HCO}_{3}\right)$ containing fluorine-18 followed by flushing the cartridge with $1 \mathrm{~mL}$ acetonitrile. Over $80 \%$ of the fluorine-18 was eluted from the Sep-Pak. HPLC analysis of the reaction mixture revealed clean radiochemical conversion (Figure 2A). The identity of 6-[ $\left.{ }^{18} \mathrm{~F}\right] \mathrm{SFPy}$ was confirmed by comparing the HPLC retention time with co-injected, authentic nonradioactive standards (Figure $2 \mathrm{~B}$ ). The $\left[{ }^{18} \mathrm{~F}\right]$ fluoride elution efficiency is comparable to the elution efficiency previously observed for the TFP-ester [35,36]. Reducing the amount of precursor (3) resulted in a lower elution of fluoride from the Sep-Pak. The analysis of the decayed reaction mixture of $6-\left[{ }^{18} \mathrm{~F}\right] \mathrm{SFPy}$ by mass spectrometry revealed the formation of a known side product, NHS ester with succinimidyl ether linkage at the 6-position of the pyridine ring (4) [34]. The unreacted precursor from the crude reaction mixture of 6-[ $\left.{ }^{18} \mathrm{~F}\right] \mathrm{SFPy}$ was completely removed by passing the mixture through an activated oasis MCX plus cartridge (Figure 2C). However, the side product (4), which is potentially an active substrate for the conjugation reaction, was not removed by this purification method (Figure $2 \mathrm{C}$ ). The identity of the pure $6-\left[{ }^{18} \mathrm{~F}\right] \mathrm{SFPy}$ was confirmed by comparing the HPLC retention time with co-injected, authentic nonradioactive standards (Figure 2D). Slow hydrolysis of $6-\left[{ }^{18} \mathrm{~F}\right] \mathrm{SFPy}$ to $6-\left[{ }^{18} \mathrm{~F}\right]$ fluoronicotinic acid was observed with time (15\% conversion after $4 \mathrm{~h}$ post radiolabeling) at room temperature (Figure $2 \mathrm{E}$ ). Compound 4 was independently prepared by reacting compound 3 with N-hydroxysuccinimide (NHS) to quantify the concentration of this compound in the final solution of 6-[ $\left.{ }^{18} \mathrm{~F}\right]$ SFPy. A calibration curve was generated using a known amount of 4 and using this curve a typical radiolabeling reaction starting with $8.9 \mathrm{mg}$ of precursor (3) and $3.88 \mathrm{GBq}(105 \mathrm{mCi})$ of $\left[{ }^{18} \mathrm{~F}\right]$ fluoride, generated $46 \mu \mathrm{g}(0.14 \mu \mathrm{mol})$ of side product, which is 7-11 mol\% of the protected peptide precursor (5) we intended to use (3-5 mg, 1.26-2.11 $\mu \mathrm{mol}$ ) for the conjugation reaction. The impurity (4) can be removed by a time-consuming HPLC purification followed by a solvent exchange process with significant loss of radioactivity due to transfer and decay of 6-[ $\left.{ }^{18} \mathrm{~F}\right] \mathrm{SFPy}$. This whole purification process might not be advantageous over the presence of the impurity in the labeled prosthetic group. Moreover, the final radiolabeled peptide (6- $\left.\left[{ }^{18} \mathrm{~F}\right] \mathrm{FPy}-\mathrm{T} 140\right)$, will be purified by HPLC which will remove the impurities generated by 4 . Therefore, no attempts were made to further purify the prosthetic group, 6- $\left[{ }^{18} \mathrm{~F}\right] \mathrm{SFP} y$.

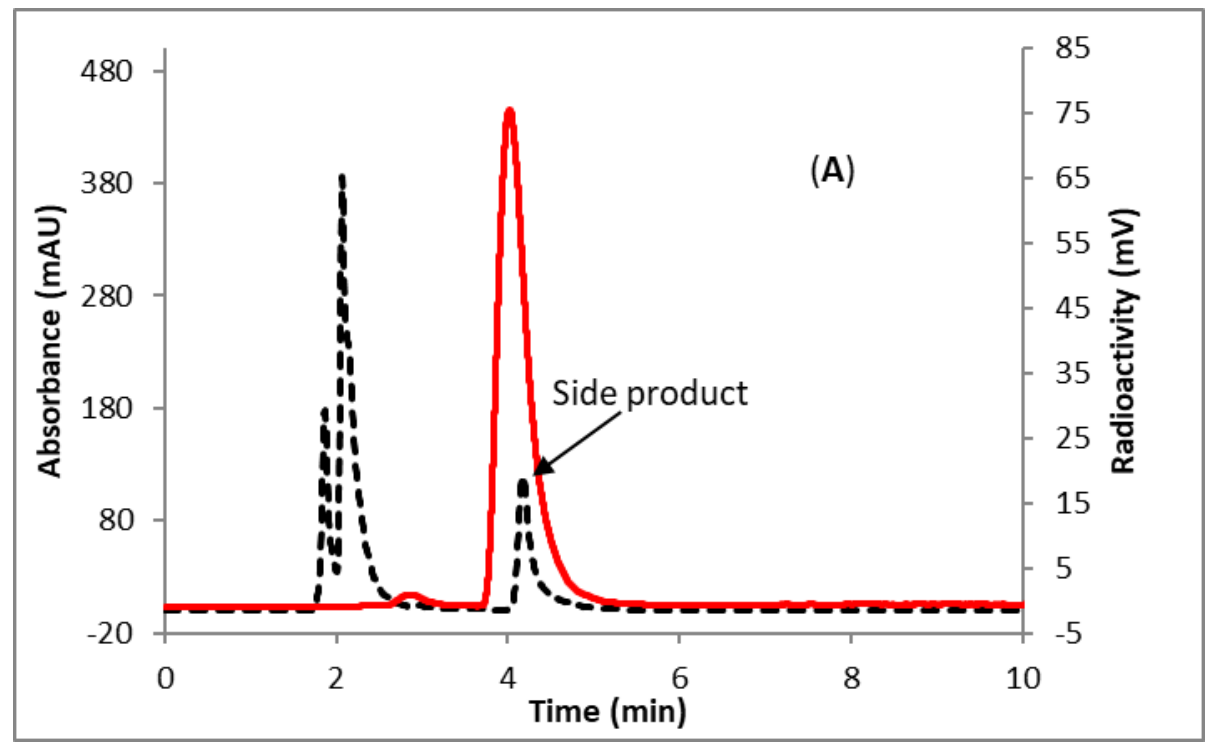

Figure 2. Cont. 

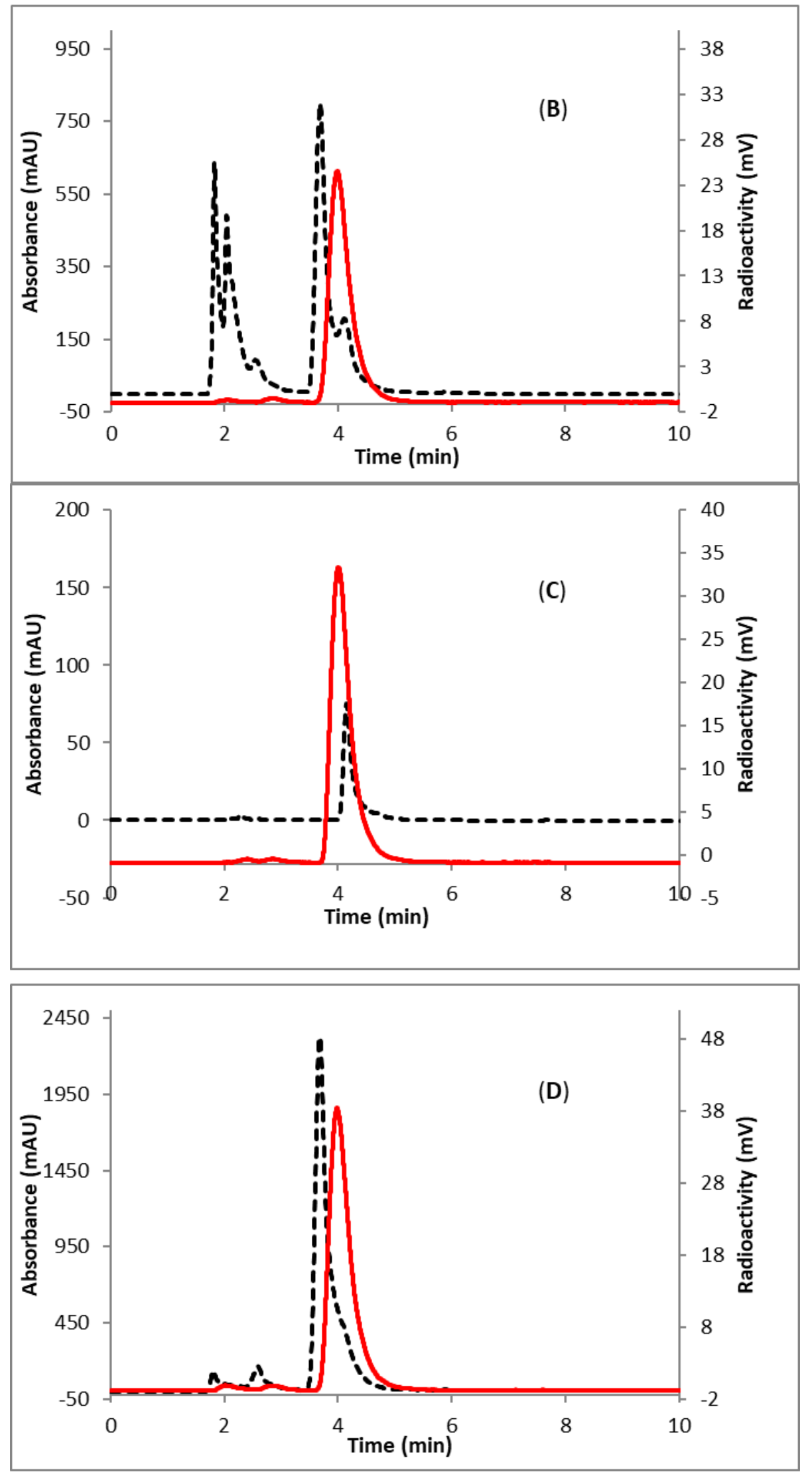

Figure 2. Cont. 


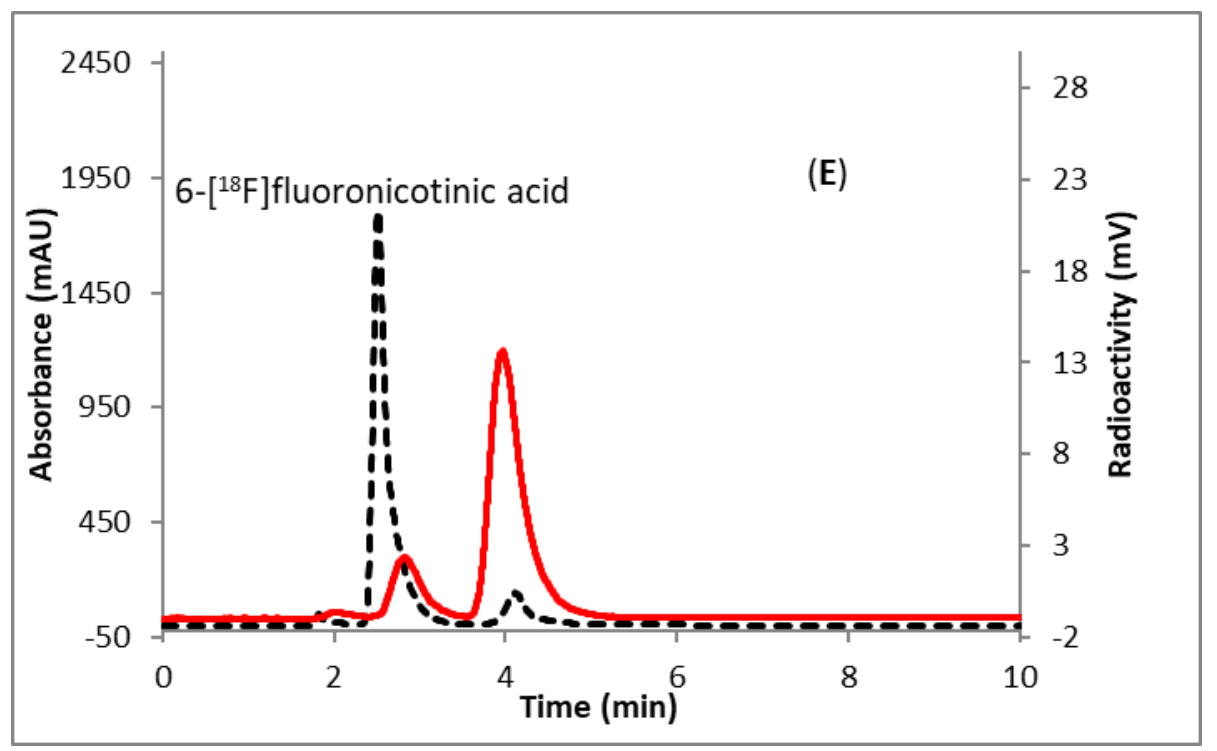

Figure 2. HPLC analysis (method B) of 6-[ $\left.{ }^{18} \mathrm{~F}\right] \mathrm{SFPy}$ (A) Crude reaction mixture; (B) Crude reaction mixture co-injected with the non-radioactive standard; (C) Pure; (D) Pure co-injected with the non-radioactive standard; (E) After $4 \mathrm{~h}$ of labeling at room temperature co-injected with the non-radioactive standard, 6-fluoronicotinic acid. Solid line, in-line radio detector; dotted line, UV detector at $254 \mathrm{~nm}$. Retention time (min): 6- $\left[{ }^{18} \mathrm{~F}\right] \mathrm{SFPy}, 4.0$; compound 4, 4.1; 6- $\left[{ }^{18} \mathrm{~F}\right]$ fluoronicotinic acid, 2.8 .

The solvent from the $6-\left[{ }^{18} \mathrm{~F}\right] \mathrm{SFPy}$ solution was removed under vacuum and $\mathrm{N}_{2}$ flow at $45{ }^{\circ} \mathrm{C}$ with no significant loss of activity. Amide bond formation with protected peptide precursor (5, Scheme 1$)$ in dimethyl sulfoxide was tested at room temperature, $40{ }^{\circ} \mathrm{C}$, and $60^{\circ} \mathrm{C}$. The radiochemical conversion determined by analytical HPLC was 3\%, 6\%, and 33\% respectively. The effect of further increasing temperature on the radiochemical conversion was not tested due to the presence of a disulfide bond that might not be stable at high temperatures. Finally, deprotecting the Dde protecting group of the labeled peptide with hydrazine solution followed by HPLC purification produced $>99 \%$ radiochemically pure 6-[ ${ }^{18}$ F]FPy-T140.

After manual optimization of the radiolabeling procedure with a low amount of radioactivity, we focused on the development of the automated synthesis of $6-\left[{ }^{18} \mathrm{~F}\right] \mathrm{FPy}-\mathrm{T} 140$ on a GE FX-N Pro Module. The direct radiolabeling of biomolecules such as peptides or proteins is difficult due to the usual requirement of high temperature and base to form the ${ }^{C}-{ }^{18} \mathrm{~F}$ bond. Although there are a few examples of direct fluorine-18 labeling of peptides, labeling is typically performed using an indirect method [39-42]. Therefore, a fully automated synthesis is challenging due to the complexity of the indirect labeling method [43-47]. The steps involved for the preparation of fluorine-18 labeled prosthetic group via currently developed Sep-Pak method (catching of fluorine-18 on an anion exchange cartridge, drying of the cartridge, release of fluorine-18 with precursor), are equivalent to the initial processing of fluorine-18 for conventional nucleophilic fluorination (catching of fluorine-18 on an anion exchange cartridge, the release of fluorine- 18 with base, azeotropic drying with acetonitrile). However, this method has several advantages including less time-consuming with no added base, resulting in producing the radiolabeling synthon in a significantly simplified process and comparable yield to the conventional labeling method. The simplified process of the 'fluorination on the Sep-Pak' method, combined with minor modifications on the GE module, readily allows for automated indirect labeling of the peptide. 
An external three-way valve was added before the V10 valve (Figure 3) on the GE Tracerlab module (GE FX-N Pro) to accomplish the Sep-Pak preparation of 6-[ $\left.{ }^{18} \mathrm{~F}\right] \mathrm{SFPy}$. An Oasis MCX cartridge was incorporated between V13 and reactor 1 for the purification of $6-\left[{ }^{18} \mathrm{~F}\right] \mathrm{SFPy}$ esters. The entire process was automated except the step to pass the precursor solution through the Sep-Pak containing fluorine-18. This part was done manually for better control of the elution rate. To perform this operation a line from the external valve was kept out of the hot cell while the rest of the system was inside the hot cell. The peptide precursor (3-5 mg) in DMSO, 2\% (v/v) hydrazine, and HPLC buffer were added in Vials 3-5, respectively (Figure 3). Phosphate-buffered saline (PBS) (pH 7.4), ethanol, and water were added in Vials 12-14, respectively for the final formulation of 6-[ ${ }^{18}$ F]FPy-T140. The overall radiochemical yield ( 2 steps) of the synthesis was $6-17 \%(n=15$, decay corrected) in a 90 min procedure. The radiochemical purity was $>99 \%$ (Figure $4 \mathrm{~A}$ ) with a molar activity of 32-100 GBq/ $\mu \mathrm{mol}$. The comparable molar activity with other routinely prepared fluorine-18 labeled tracers in our lab and the absence of any UV peak (Figure 4A) indicated that all chemical impurities were successfully removed. The identity of the product was confirmed by comparing the HPLC retention time with co-injected, authentic nonradioactive standards (Figure 4B). In a typical reaction starting with $7.3 \mathrm{GBq}(197 \mathrm{mCi})$ of $\left[{ }^{18} \mathrm{~F}\right]$ fluoride on the Sep-Pak, $0.7 \mathrm{GBq}(19 \mathrm{mCi})$ of the product was obtained. Fluorine-18 labeled nicotinic acid tetrafluorophenyl ester (6- $\left.\left[{ }^{18} \mathrm{~F}\right] \mathrm{FPy}-\mathrm{TFP}\right)$ was prepared according to the literature method to compare the overall RCYs of $6-\left[{ }^{18} \mathrm{~F}\right] \mathrm{FPy}-\mathrm{T} 140$ prepared either using 6-[ $\left.{ }^{18} \mathrm{~F}\right] \mathrm{SFPy}$ or 6- $\left[{ }^{18} \mathrm{~F}\right] \mathrm{FPy}$-TFP $[35,36]$. The conjugation of 6-[ $\left.{ }^{18} \mathrm{~F}\right] \mathrm{FPy}$-TFP and deprotection of the Dde protecting group were performed following the same protocol used to prepare $6-\left[{ }^{18} \mathrm{~F}\right] \mathrm{FPy}-\mathrm{T} 140$ from 6-[ $\left.{ }^{18} \mathrm{~F}\right] \mathrm{SFPy}$. Similar RCYs of $\left[{ }^{18} \mathrm{~F}\right] \mathrm{FPy}-\mathrm{T} 140$ were observed from both the prosthetic groups $(5-16 \%, n=6$ vs. $6-17 \%, n=15)$.

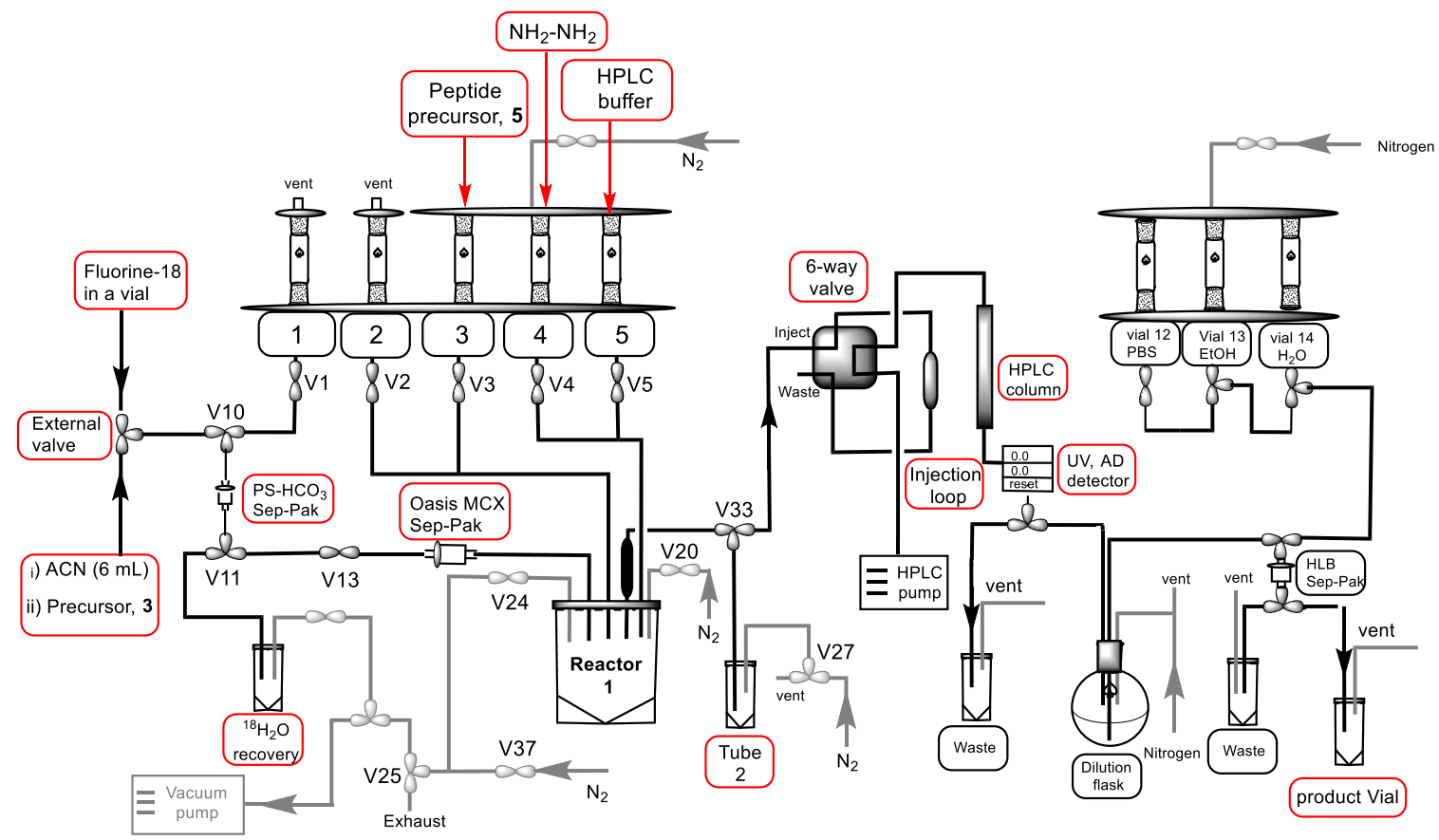

Figure 3. Schematic diagram of the automated synthesis of $6-\left[{ }^{18} \mathrm{~F}\right] \mathrm{FPy}-\mathrm{CONH}-\mathrm{T} 140$ on GE FX-N Pro Module. 

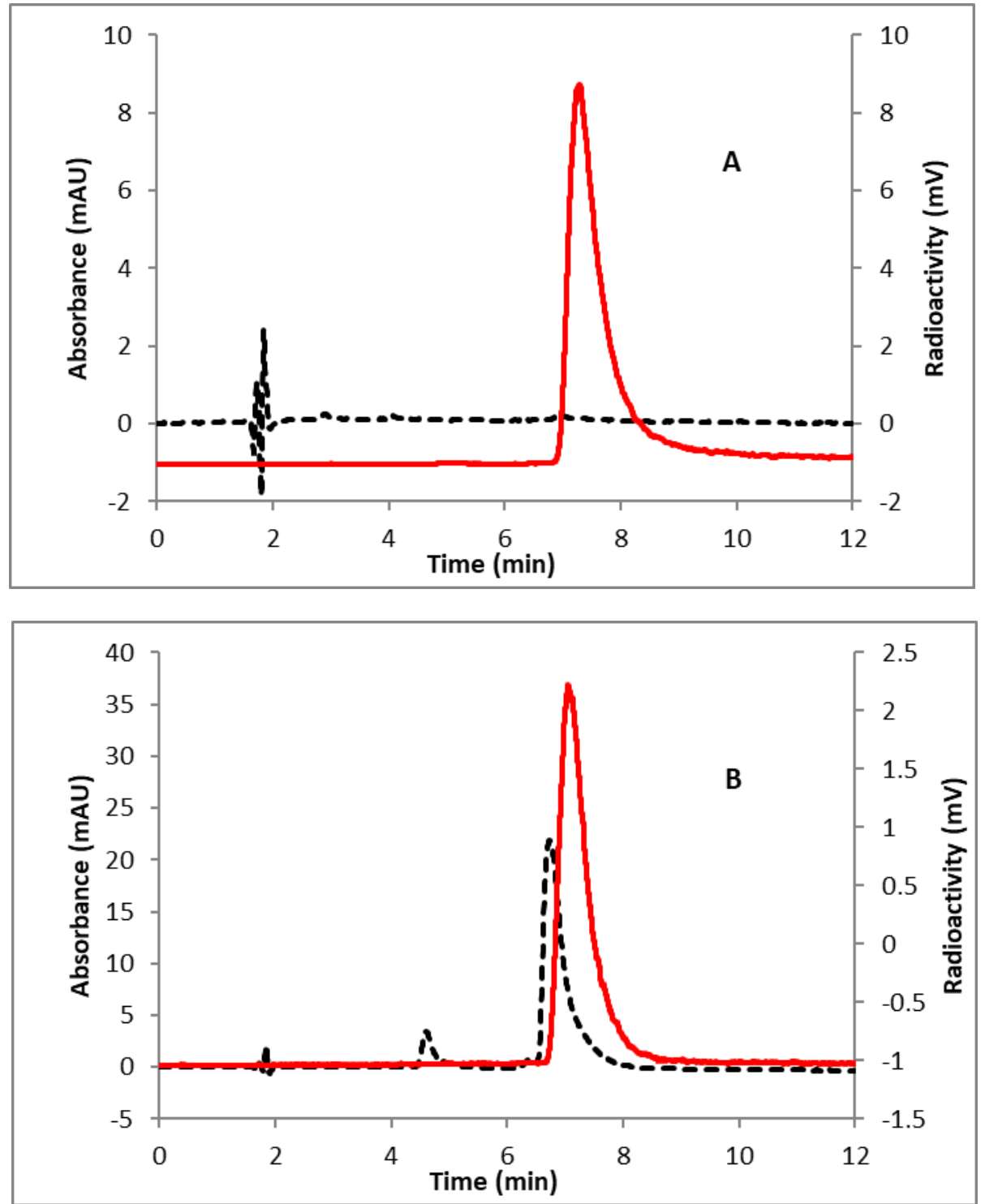

Figure 4. HPLC analysis (method B) of (A) 6-[18 F]FPy-T140; (B) 6-[ $\left.{ }^{18} \mathrm{~F}\right] \mathrm{FPy}-\mathrm{T} 140$ co-injected with the non-radioactive standard. Solid line, in-line radio detector; dotted line, UV detector at $254 \mathrm{~nm}$. Retention time (min): 6-[ $\left.{ }^{18} \mathrm{~F}\right] \mathrm{FPy}-\mathrm{T} 140,7.3$.

\subsection{In Vitro Binding Assays}

6- $\left[{ }^{18} \mathrm{~F}\right] \mathrm{FPy}-\mathrm{T} 140$ exhibited high-affinity binding with a $\mathrm{K}_{\mathrm{d}}$ of $0.19 \pm 0.03 \mathrm{nM}$ (mean $\left.\pm \mathrm{SE} ; n=6\right)$ determined from saturation binding studies using the HeLa (moderate CXCR4 expression) cancer cell line (Figure 5). This $\mathrm{K}_{\mathrm{d}}$ value compared favorably with previously reported $\mathrm{IC}_{50}$ values of the T-140 peptide $(2.4 \mathrm{nM})$ and other T140 analogs (4-FBz-T140 analog $=0.99 \mathrm{nM}, 1.75 \mathrm{nM}$; 4-F-T140 = $2.5 \mathrm{nM} ;$ T140-2D = $2.47 \mathrm{nM} ;$ Ac-Tz14011 = $1.2 \mathrm{nM} ;$ In-DPTA-Ac-TZ14011 = $7.9 \mathrm{nM}$; Ga-DOTA 4-FBz-TN14003 $=1.04 \mathrm{nM}$; DOTA-NFB T140 $=68 \mathrm{nM}$ ). The $\mathrm{K}_{\mathrm{d}}$ value was at least 3-fold lower suggesting that this analog, 6-[ $\left.{ }^{18} \mathrm{~F}\right] \mathrm{FPy}-\mathrm{T} 140$, has a higher affinity [24,31,48-51]. From the cell assays, the CXCR4 concentration $\left(\mathrm{B}_{\max }\right)$ on HeLa cells was $2.76 \pm 0.51 \times 10^{5}$ receptors per cell (mean $\pm \mathrm{SE} ; n=6$ ), which was consistent with immunofluorescence staining results by Peng et al. in which significant CXCR4 expression was observed with HeLa cells [52]. 


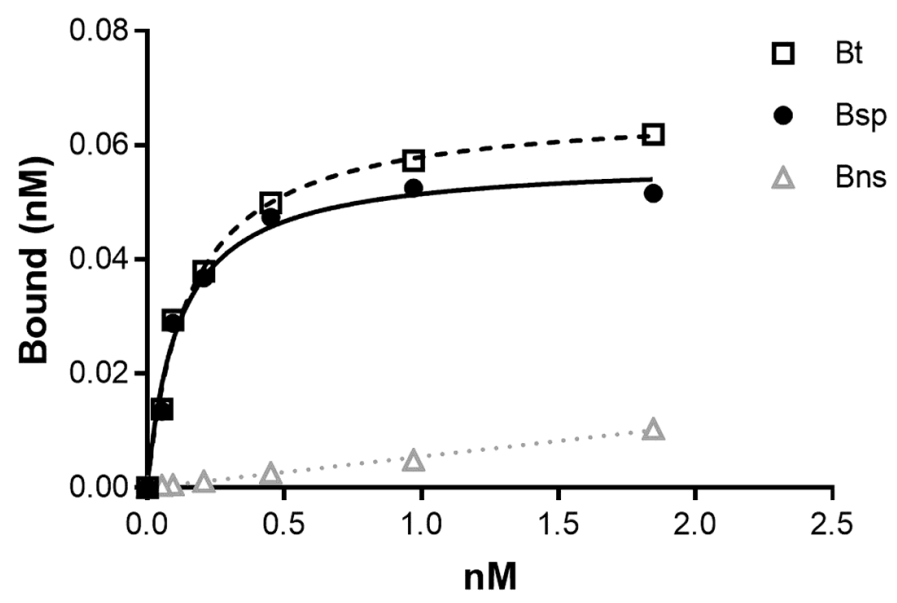

Figure 5. Representative plot from an in vitro 6-[ $\left.{ }^{18} \mathrm{~F}\right] \mathrm{FPy}-\mathrm{T} 140$ saturation binding assay using HeLa cells with each point representing the average of duplicates. $\mathrm{B}_{\mathrm{t}}=$ Btotal; Bns = Bnon-specific (determined in the presence of $10^{-6} \mathrm{M}$ unlabeled T-140 peptide); Bsp = Bspecific (Bt-Bns).

\section{Materials and Methods}

Non-radioactive standard (6-FPy-T140) and 1-(4,4-dimethyl-2,6-dioxocyclohexylidene) ethyl (Dde, 5) protected peptide precursor T140 were obtained from CS Bio Co. (Menlo Park, CA, USA). Fluorine-18 was received from the National Institutes of Health cyclotron facility (Bethesda, MD, USA). Phosphate-buffered saline (PBS) 1X (12 mM phosphate buffer, pH 7.4, $137 \mathrm{mM} \mathrm{NaCl}$, and $2.7 \mathrm{mM}$ $\mathrm{KCl}$ ) was obtained from Life Technologies (Carlsbad, CA, USA). All other chemicals and solvents were received from Sigma Aldrich (St. Louis, MO, USA) and used without further purification. For all fluorine-18 elutions, anhydrous solvents were used. Chromafix 30-PS- $\mathrm{HCO}_{3}$ anion-exchange Sep-Pak cartridges were purchased from Macherey-Nagel (Düren, Germany) and the packing material was reduced to half $(\sim 20 \mathrm{mg})$. Other columns and the Sep-Pak ${ }^{\circledR}$ cartridges used in this synthesis were obtained from Agilent Technologies (Santa Clara, CA, USA) and Waters (Milford, MA, USA), respectively. Oasis MCX Plus cartridges were conditioned by passing $5 \mathrm{~mL}$ acetonitrile through them. Sep-Pak light C18 cartridges were conditioned with a sequence of $5 \mathrm{~mL}$ ethanol, $10 \mathrm{~mL}$ air, and $10 \mathrm{~mL}$ water. Mass spectra (MS) were recorded on a 6130 Quadrupole LC/MS, Agilent Technologies instrument equipped with a diode array detector. ${ }^{1} \mathrm{H},{ }^{13} \mathrm{C}$, and ${ }^{19} \mathrm{~F}-\mathrm{NMR}$ spectra were recorded on a $400 \mathrm{MHz}$ Bruker spectrometer. Chemical shifts (ppm) were reported relative to the solvent residual peaks of dimethyl sulfoxide $\left(\delta^{1} \mathrm{H}, 2.54 \mathrm{ppm} ;{ }^{13} \mathrm{C} 40.45\right)$, and chloroform $\left(\delta^{1} \mathrm{H}, 7.26 \mathrm{ppm}\right) .{ }^{19} \mathrm{~F}-\mathrm{NMR}$ spectra were reported using trifluoroacetic acid as a reference $\left({ }^{19} \mathrm{~F},-76.72 \mathrm{ppm}\right)$. High-performance liquid chromatography (HPLC) purification and analytical HPLC analyses for radiochemical work were performed on an Agilent 1200 Series instrument equipped with multi-wavelength detectors along with a flow count radio detector (Eckert \& Ziegler, B-FC-3500 diode).

Method A (HPLC conditions for purification): Vydac C-4 (2) column $(10 \times 250 \mathrm{~mm}, 5 \mu)$, mobile phase: $18 \% \mathrm{~B}$ in $\mathrm{A}$; $\mathrm{B}=$ acetonitrile $(0.1 \% \mathrm{TFA}), \mathrm{A}=$ Water $(0.1 \% \mathrm{TFA})$, flow rate of $4 \mathrm{~mL} / \mathrm{min}$; $\mathrm{t}_{R}=\sim 16 \mathrm{~min}$.

Method B (HPLC conditions for analysis): Vydac C-4 (2) column $(4.6 \times 150 \mathrm{~mm}, 5 \mu)$, mobile phase: $15-22 \% \mathrm{~B}$ in $10 \mathrm{~min}$; $\mathrm{B}=$ acetonitrile $(0.1 \% \mathrm{TFA}), \mathrm{A}=$ Water $(0.1 \% \mathrm{TFA})$, flow rate of $1 \mathrm{~mL} / \mathrm{min}$; $\mathrm{t}_{\mathrm{R}}=\sim 8 \mathrm{~min}$.

\subsection{Synthesis of Precursor}

Synthesis of 6-N,N,N-Trimethylammonium Nicotinic Acid NHS Ester Triflate Salt (3)

To a solution of 6-chloronicotinic acid NHS ester $(\mathbf{1}, 500 \mathrm{mg}, 1.97 \mathrm{mmol})$ in anhydrous tetrahydrofuran (THF, $30 \mathrm{~mL}$ ) at $0{ }^{\circ} \mathrm{C}$, was added a solution of triethylamine ( $2 \mathrm{~mL} 1 \mathrm{M}$ in THF, $2 \mathrm{mmol}$ ) 
with stirring. The reaction mixture was slowly allowed to warm up to room temperature and stirred for $24 \mathrm{~h}$. The white precipitate was collected by filtration and washed with diethyl ether to produce the chloride salt of trimethylammonium nicotinic acid NHS ester $(2,500 \mathrm{mg}, 1.6 \mathrm{mmol})$. To the suspension of $\mathbf{2}$ in anhydrous dichloromethane was added $1 \mathrm{~mL}$ trimethylsilyl trifluoromethanesulfonate (TMSOTf) and the mixture was stirred for $4 \mathrm{~h}$ followed by evaporation of the solvent under reduced pressure. The product was recrystallized by layering diethyl ether on top of the acetonitrile solution of 3 . After 4 days, the white crystals were collected and dried under reduced pressure $(480 \mathrm{mg}, 1.2 \mathrm{mmol}$, 55\%, overall). ${ }^{1} \mathrm{H}-\mathrm{NMR}(400 \mathrm{MHz}, \mathrm{DMSO}-\mathrm{d} 6) \delta 9.32(\mathrm{~d}, J=2.5 \mathrm{~Hz}, 1 \mathrm{H}), 8.92(\mathrm{dd}, J=8.8,2.4 \mathrm{~Hz}$, $1 \mathrm{H}), 8.36(\mathrm{~d}, J=8.7 \mathrm{~Hz}, 1 \mathrm{H}), 3.65(\mathrm{~s}, 9 \mathrm{H}), 2.94(\mathrm{~s}, 4 \mathrm{H}) .{ }^{13} \mathrm{C}-\mathrm{NMR}(101 \mathrm{MHz}, \mathrm{DMSO}-\mathrm{d} 6) \delta 170.4,161.2$, 160.20, 150.4, 143.4, 123.7, 117.1, 55.2, 26.1. ${ }^{19} \mathrm{~F}-\mathrm{NMR}$ (376 MHz, DMSO-d6) $\delta$-77.77. MS (Electrospray ionization, ESI) calculated mass for the parent $\mathrm{C}_{13} \mathrm{H}_{16} \mathrm{~N}_{3} \mathrm{O}_{4}$ [M-OTf], 278.1, found 278.1 [M-OTf].

\subsection{Synthesis of Side Product, 2,5-Dioxopyrrolidin-1-yl 6-((2,5-Dioxopyrrolidin-1-yl)Oxy)Nicotinate, (4)}

To the solution of NHS $(25.4 \mathrm{mg}, 0.22 \mathrm{mmol})$ and triethylamine $(5 \mu \mathrm{L})$ in anhydrous acetonitrile $(1 \mathrm{~mL})$ was added a solution of $3(100 \mathrm{mg}, 0.23 \mathrm{mmol})$ in anhydrous acetonitrile $(1 \mathrm{ml})$ and stirred for $1 \mathrm{~h}$. The solvent was evaporated under reduced pressure. The residue was dissolved in dichloromethane and washed with water. The dichloromethane layer was dried with $\mathrm{MgSO}_{4}$ and the solvent was evaporated under reduced pressure to obtain $4(60 \mathrm{mg}, 0.18 \mathrm{mmol}, 78 \%)$ as a white solid. ${ }^{1} \mathrm{H}-\mathrm{NMR}(400 \mathrm{MHz}$, Chloroform-d) $\delta 8.86(\mathrm{~s}, 1 \mathrm{H}), 8.44(\mathrm{~d}, J=8.7 \mathrm{~Hz}, 1 \mathrm{H}), 7.22(\mathrm{~d}, J=8.7 \mathrm{~Hz}, 1 \mathrm{H}), 2.92(\mathrm{~d}, J=8.8 \mathrm{~Hz}, 8 \mathrm{H})$. ${ }^{13} \mathrm{C}-\mathrm{NMR}\left(101 \mathrm{MHz}, \mathrm{CDCl}_{3}\right) \delta 169.4,168.8,164.2,160.0,150.7,141.8,119.2,109.3,25.6,25.6 . \mathrm{MS}$ (ESI) calculated mass for the parent $\mathrm{C}_{14} \mathrm{H}_{11} \mathrm{~N}_{3} \mathrm{O}_{7}, 334.1[\mathrm{M}+\mathrm{H}]$, found $334[\mathrm{M}+\mathrm{H}]^{+}$.

\subsection{Radiosynthesis of $6-\left[{ }^{18} \mathrm{~F}\right] F P y-T 140$}

\subsubsection{Manual Synthesis}

Fluorine-18 labeled target water (370-740 MBq) was diluted with $2 \mathrm{~mL}$ water and passed through an anion-exchange cartridge (Chromafix 30-PS- $\mathrm{HCO}_{3}$ ). The cartridge was washed with anhydrous acetonitrile $(6 \mathrm{~mL})$ and dried for $1 \mathrm{~min}$ under vacuum. The $\left[{ }^{18} \mathrm{~F}\right]$ fluoride from the Sep-Pak was slowly eluted $(0.5 \mathrm{~mL} / \mathrm{min})$ with $6-N, N, N$-trimethylaminium nicotinic acid NHS ester triflate salt $(3,5-7 \mathrm{mg})$ in $0.5 \mathrm{~mL} \mathrm{1:4} \mathrm{acetonitrile:t-butanol} \mathrm{through} \mathrm{an} \mathrm{activated} \mathrm{Oasis} \mathrm{MCX} \mathrm{Plus} \mathrm{cartridge.} \mathrm{The} \mathrm{Sep-Pak}$ was further eluted with $1 \mathrm{~mL}$ acetonitrile and the eluent was collected in the same vial. The solvent was evaporated under $\mathrm{N}_{2}$ /vacuum at $45^{\circ} \mathrm{C}$. To the dried $6-\left[{ }^{18} \mathrm{~F}\right] \mathrm{SFP}$, was added a mixture of peptide precursor $(5,3-5 \mathrm{mg})$ in dimethyl sulfoxide (DMSO, $0.3 \mathrm{~mL})$ and triethylamine $(5 \mu \mathrm{L})$ followed by heating at $60{ }^{\circ} \mathrm{C}$ for $25 \mathrm{~min}$. Hydrazine solution $(0.5 \mathrm{~mL}$ of $2 \%$ solution, $v / v)$ was added and kept at $60{ }^{\circ} \mathrm{C}$ for $10 \mathrm{~min}$. HPLC buffer (18\% acetonitrile in water with $\left.0.1 \% \mathrm{TFA} ; 3 \mathrm{~mL}\right)$ was added and the mixture was injected into the HPLC for purification (method A).

\subsubsection{Automated Synthesis}

Fluorine-18 labeled target water (3700-7400 MBq) was diluted with $2 \mathrm{~mL}$ water and passed through an anion-exchange cartridge (Chromafix 30-PS- $\mathrm{HCO}_{3}$ ) followed by anhydrous acetonitrile $(6 \mathrm{~mL})$ and the cartridge was dried for $1 \mathrm{~min}$ under vacuum. The $\left[{ }^{18} \mathrm{~F}\right]$ fluoride from the Sep-Pak was eluted with either the NHS ester (3) or TFP ester of the triflate salt of 6-N,N,N-trimethylaminium

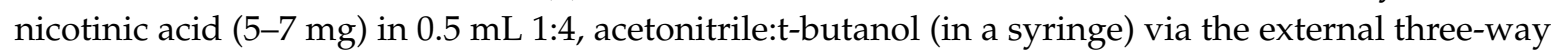
valve. The mixture was passed through a pre-conditioned Oasis MCX Plus cartridge (incorporated between V13 and Reactor 1). The cartridge was flushed with $1 \mathrm{~mL}$ acetonitrile using the same line and the eluent was collected in the Reactor 1 . The solvent was evaporated under $\mathrm{N}_{2} /$ vacuum either at $45{ }^{\circ} \mathrm{C}$. To the dried fluorine-18 labeled reactive ester in Reactor 1 was added a mixture of peptide precursor $(5,3-5 \mathrm{mg})$ and triethylamine $(5 \mu \mathrm{L})$ in DMSO $(0.5 \mathrm{~mL})$ from Vial 3. The solution was stirred for $25 \mathrm{~min}$ at $60{ }^{\circ} \mathrm{C}$ followed by the addition of hydrazine solution $(0.5 \mathrm{~mL} \%, v / v)$ from Vial 4 and stirring was continued for $10 \mathrm{~min}$ at $60^{\circ} \mathrm{C}$. HPLC buffer $(3 \mathrm{~mL})$ was added from Vial 5 and the solution 
was transferred to Tube 2 for HPLC purification. The product fraction was collected in the dilution flask containing $20 \mathrm{~mL}$ water. The solution was passed through a Sep-Pak light C18 cartridge to retain the product. The cartridge was washed with water $(6 \mathrm{~mL})$ from Vial 14. The product was eluted with ethanol $(1 \mathrm{~mL})$ from vial 13 followed by PBS 1 X $(3 \mathrm{~mL})$ from Vial 12 in a product vial.

\subsection{In Vitro Studies}

The human cervical carcinoma cell line, HeLa (moderate CXCR4 expression), was purchased from ATCC (Gaithersburg, MD) and grown in DMEM supplemented with $4 \mathrm{mM} \mathrm{L-glutamine,} 1 \mathrm{mM}$ sodium pyruvate, $10 \%$ fetal bovine serum (FBS) and $1 \%$ Pen/Strep/Amphotericin B at $37{ }^{\circ} \mathrm{C}$ in a $5 \%$ $\mathrm{CO}_{2}$ humidified atmosphere.

For the saturation assays sub-confluent HeLa cells were harvested (0.125\% Trypsin-EDTA) and resuspended in binding buffer (RPMI 1640 containing $20 \mathrm{mM}$ HEPES and 0.5\% $(w / v)$ bovine serum albumin (BSA), pH 7.0).

Saturation studies were performed by adding increasing concentrations of 6- $\left[{ }^{18} \mathrm{~F}\right] \mathrm{FPy}-\mathrm{CONH}-\mathrm{T} 140$ $\left(0.05 \mathrm{nM}\right.$ to $\left.\left.2.5 \mathrm{nM} ; \mathrm{B}_{\mathrm{t}}\right)\right)$ to duplicate tubes with a constant concentration of HeLa cells $\left(0.50\right.$ to $1.1 \times 10^{5}$ cells per tube); non-specific binding $\left(\mathrm{B}_{\mathrm{nsb}}\right)$ was determined by adding unlabeled 6-FPy-T140 peptide $\left(10^{-6} \mathrm{M}\right)$ to another set of duplicates at the same labeled peptide concentrations. Following incubation for $1 \mathrm{~h}$ at $37^{\circ} \mathrm{C}$, the cell-bound $6-\left[{ }^{18} \mathrm{~F}\right] \mathrm{FPy}-\mathrm{T} 140$ was separated from the free radioligand by centrifuging, and washing twice (PBS). After aspirating the samples, the radioactive content of the cell pellets was determined by gamma counting (Perkin Elmer 2480 Wizard 2, Shelton, CT). The $\mathrm{K}_{\mathrm{d}}$ and $\mathrm{B}_{\max }$ were determined from 6 to 8 concentrations of $6-\left[{ }^{18} \mathrm{~F}\right] \mathrm{FPy}-\mathrm{T} 140$ and analyzed using non-linear regression curve fits including a one-site binding hyperbola for saturation studies (GraphPad PRISM version 7.05 for Windows, GraphPad Software, San Diego, CA, USA; www.graphpad.com).

\section{Conclusions}

$6-\left[{ }^{18} \mathrm{~F}\right] \mathrm{SFPy}$ was prepared in high yield using 'fluorination on the Sep-Pak' method. The conjugation of 6- $\left[{ }^{18} \mathrm{~F}\right] \mathrm{SFPy}$ with peptide precursor was used to produce a new tracer, $6-\left[{ }^{18} \mathrm{~F}\right] \mathrm{FPy}-\mathrm{T} 140$. The simplicity of this labeling procedure allows us to successfully develop an automated synthesis method. In vitro assays demonstrated that $6-\left[{ }^{18} \mathrm{~F}\right] \mathrm{FPy}-\mathrm{T} 140$ exhibited sub-nanomolar binding affinity $(\mathrm{Kd} \sim 0.2 \mathrm{nM})$ for CXCR4 indicating that the biological activity of the peptide had been retained.

Author Contributions: Conceptualization, F.B., E.M.J.; data curation, F.B., X.Z., E.M.J.; formal analysis, F.B., X.Z., E.M.J., T.E.P.; methodology, F.B., X.Z., B.B., T.E.P., E.M.J.; supervision, R.E.S., P.L.C.; writing—original draft, F.B.; writing-review and editing, F.B., X.Z., T.E.P., E.M.J., P.L.C., R.E.S. All authors have read and agreed to the published version of the manuscript.

Funding: This project has been funded in whole or in part with federal funds from the National Cancer Institute, National Institutes of Health, under Contract No. HHSN261200800001E.

Conflicts of Interest: The authors declare no conflict of interest.

\section{References}

1. Scholten, D.; Canals, M.; Maussang, D.; Roumen, L.; Smit, M.; Wijtmans, M.; De Graaf, C.; Vischer, H.; Leurs, R. Pharmacological modulation of chemokine receptor function. Br. J. Pharmacol. 2012, 165, 1617-1643. [CrossRef] [PubMed]

2. Bleul, C.C.; Wu, L.; Hoxie, J.A.; Springer, T.A.; Mackay, C.R. The HIV coreceptors CXCR4 and CCR5 are differentially expressed and regulated on human T lymphocytes. Proc. Natl. Acad. Sci. USA 1997, 94, 1925-1930. [CrossRef] [PubMed]

3. Oberlin, E.; Amara, A.; Bachelerie, F.; Bessia, C.; Virelizier, J.-L.; Arenzana-Seisdedos, F.; Schwartz, O.; Heard, J.-M.; Clark-Lewis, I.; Legler, D.F.; et al. The CXC chemokine SDF-1 is the ligand for LESTR/fusin and prevents infection by T-cell-line-adapted HIV-1. Nature 1996, 382, 833-835. [CrossRef]

4. Bleul, C.C.; Farzan, M.; Choe, H.; Parolin, C.; Clark-Lewis, I.; Sodroski, J.; Springer, T.A. The lymphocyte chemoattractant SDF-1 is a ligand for LESTR/fusin and blocks HIV-1 entry. Nature 1996, 382, 829-833. [CrossRef] 
5. Klein, R.S.; Rubin, J.B. Immune and nervous system CXCL12 and CXCR4: Parallel roles in patterning and plasticity. Trends Immunol. 2004, 25, 306-314. [CrossRef] [PubMed]

6. Wu, B.; Chien, E.Y.T.; Mol, C.D.; Fenalti, G.; Liu, W.; Katritch, V.; Abagyan, R.; Brooun, A.; Wells, P.; Bi, F.C.; et al. Structures of the CXCR4 Chemokine GPCR with Small-Molecule and Cyclic Peptide Antagonists. Science 2010, 330, 1066-1071. [CrossRef] [PubMed]

7. Balkwill, F.; Balkwill, F. The significance of cancer cell expression of the chemokine receptor CXCR4. Semin. Cancer Biol. 2004, 14, 171-179. [CrossRef]

8. Zlotnik, A. Chemokines and cancer. Int. J. Cancer 2006, 119, 2026-2029. [CrossRef]

9. Chatterjee, S.; Azad, B.B.; Nimmagadda, S. The Intricate Role of CXCR4 in Cancer. Adv. Cancer Res. 2014, 124, 31-82. [CrossRef]

10. Janowski, M. Functional diversity of SDF-1 splicing variants. Cell Adhes. Migr. 2009, 3, 243-249. [CrossRef]

11. Nagasawa, T.; Kikutani, H.; Kishimoto, T. Molecular cloning and structure of a pre-B-cell growth-stimulating factor. Proc. Natl. Acad. Sci. USA 1994, 91, 2305-2309. [CrossRef] [PubMed]

12. Kucia, M.; Jankowski, K.; Reca, R.; Wysoczynski, M.; Bandura, L.; Allendorf, D.J.; Zhang, J.; Ratajczak, J.; Ratajczak, M.Z. CXCR4-SDF-1 signalling, locomotion, chemotaxis and adhesion. J. Mol. Histol. 2004, 35, 233-245. [CrossRef] [PubMed]

13. Busillo, J.M.; Benovic, J.L. Regulation of CXCR4 signaling. Biochim. Biophys. Acta Biomembr. 2007, 1768, 952-963. [CrossRef] [PubMed]

14. Hernandez, P.A.; Gorlin, R.J.; Lukens, J.N.; Taniuchi, S.; Bohinjec, J.; François, F.; Klotman, M.E.; Diaz, G.A. Mutations in the chemokine receptor gene CXCR4 are associated with WHIM syndrome, a combined immunodeficiency disease. Nat. Genet. 2003, 34, 70-74. [CrossRef]

15. Wen, J.; Zhang, J.-Q.; Huang, W.; Wang, Y. SDF-1 $\alpha$ and CXCR4 as therapeutic targets in cardiovascular disease. Am. J. Cardiovasc. Dis. 2011, 2, 20-28. [PubMed]

16. Kuil, J.; Buckle, T.; Van Leeuwen, F.W. Imaging agents for the chemokine receptor 4 (CXCR4). Chem. Soc. Rev. 2012, 41, 5239. [CrossRef]

17. Weiss, I.D.; Jacobson, O. Molecular Imaging of Chemokine Receptor CXCR4. Theranostics 2013, 3, 76-84. [CrossRef]

18. Nayak, T.R.; Hong, H.; Zhang, Y.; Cai, W. Multimodality Imaging of CXCR4 in Cancer: Current Status towards Clinical Translation. Curr. Mol. Med. 2013, 13, 1538-1548. [CrossRef]

19. Tahirovic, Y.A.; Pelly, S.; Jecs, E.; Miller, E.J.; Sharma, S.K.; Liotta, D.C.; Wilson, L.J. Small molecule and peptide-based CXCR4 modulators as therapeutic agents. A patent review for the period from 2010 to 2018. Expert Opin. Ther. Patents 2020, 30, 87-101. [CrossRef]

20. Wang, J.; Tannous, B.A.; Poznansky, M.C.; Chen, H. CXCR4 antagonist AMD3100 (plerixafor): From an impurity to a therapeutic agent. Pharmacol. Res. 2020, 159, 105010. [CrossRef]

21. Adlere, I.; Caspar, B.; Arimont, M.; Dekkers, S.; Visser, K.; Stuijt, J.; De Graaf, C.; Stocks, M.; Kellam, B.; Briddon, S.; et al. Modulators of CXCR4 and CXCR7/ACKR3 Function. Mol. Pharmacol. 2019, 96, 737-752. [CrossRef]

22. Tamamura, H.; Xub, Y.; Hattorib, T.; Zhangb, X.; Arakakic, R.; Kanbarac, K.; Omagaria, A.; Otakaa, A.; Ibukaa, T.; Yamamotod, N.; et al. A Low-Molecular-Weight Inhibitor against the Chemokine Receptor CXCR4: A Strong Anti-HIV Peptide T140. Biochem. Biophys. Res. Commun. 1998, 253, 877-882. [CrossRef] [PubMed]

23. Masuda, M.; Nakashima, H.; Ueda, T.; Naba, H.; Ikoma, R.; Otaka, A.; Terakawa, Y.; Tamamura, H.; Ibuka, T.; Murakami, T.; et al. A novel anti-HIV synthetic peptide, T-22 ([Tyr5,12,Lys7]-polyphemusin II). Biochem. Biophys. Res. Commun. 1992, 189, 845-850. [CrossRef]

24. Tamamura, H.; Hori, A.; Kanzaki, N.; Hiramatsu, K.; Mizumoto, M.; Nakashima, H.; Yamamoto, N.; Otaka, A.; Fujii, N. T140 analogs as CXCR4 antagonists identified as anti-metastatic agents in the treatment of breast cancer. FEBS Lett. 2003, 550, 79-83. [CrossRef]

25. Koshiba, T.; Hosotani, R.; Miyamoto, Y.; Ida, J.; Tsuji, S.; Nakajima, S.; Kawaguchi, M.; Kobayashi, H.; Doi, R.; Hori, T.; et al. Expression of stromal cell-derived factor 1 and CXCR4 ligand receptor system in pancreatic cancer: A possible role for tumor progression. Clin. Cancer Res. 2000, 6, 3530-3535.

26. Mori, T.; Doi, R.; Koizumi, M.; Toyoda, E.; Ito, D.; Kami, K.; Masui, T.; Fujimoto, K.; Tamamura, H.; Hiramatsu, K.; et al. CXCR4 antagonist inhibits stromal cell-derived factor 1-induced migration and invasion of human pancreatic cancer. Mol. Cancer Ther. 2004, 3, 29-37. 
27. Murakami, T.; Maki, W.; Cardones, A.R.; Fang, H.; Kyi, A.T.; O Nestle, F.; Hwang, S.T. Expression of CXC chemokine receptor- 4 enhances the pulmonary metastatic potential of murine B16 melanoma cells. Cancer Res. 2002, 62, 7328-7334.

28. Juárez, J.; Bradstock, K.F.; Gottlieb, D.J.; Bendall, L.J. Effects of inhibitors of the chemokine receptor CXCR4 on acute lymphoblastic leukemia cells in vitro. Leukemia 2003, 17, 1294-1300. [CrossRef] [PubMed]

29. Burger, M.; Glodek, A.; Hartmann, T.N.; Schmitt-Gräff, A.; E Silberstein, L.; Fujii, N.; Kipps, T.J.; A Burger, J. Functional expression of CXCR4 (CD184) on small-cell lung cancer cells mediates migration, integrin activation, and adhesion to stromal cells. Oncogene 2003, 22, 8093-8101. [CrossRef]

30. Tamamura, H.; Hiramatsu, K.; Mizumoto, M.; Ueda, S.; Kusano, S.; Terakubo, S.; Akamatsu, M.; Yamamoto, N.; Trent, J.O.; Wang, Z.; et al. Enhancement of the T140-based pharmacophores leads to the development of more potent and bio-stable CXCR4 antagonists. Org. Biomol. Chem. 2003, 1, 3663-3669. [CrossRef]

31. Jacobson, O.; Weiss, I.D.; Kiesewetter, D.O.; Farber, J.M.; Chen, X. PET of Tumor CXCR4 Expression with 4-18F-T140. J. Nucl. Med. 2010, 51, 1796-1804. [CrossRef] [PubMed]

32. Yan, X.; Niu, G.; Wang, Z.; Yang, X.; Kiesewetter, D.O.; Jacobson, O.; Shen, B.; Chen, X. Al[18F]NOTA-T140 Peptide for Noninvasive Visualization of CXCR4 Expression. Mol. Imaging Biol. 2016, 18, 135-142. [CrossRef] [PubMed]

33. Siebeneicher, H.; Graham, K. Formulation of Radiopharmaceuticals Containing Multiple Acidic Groups. International Patent No. PCT/US2013/041427, 21 November 2013.

34. Richard, M.; Specklin, S.; Roche, M.; Hinnen, F.; Kuhnast, B. Original synthesis of radiolabeling precursors for batch and on resin one-step/late-stage radiofluorination of peptides. Chem. Commun. 2020, 56, 2507-2510. [CrossRef] [PubMed]

35. Basuli, F.; Zhang, X.; Jagoda, E.M.; Choyke, P.L.; Swenson, R.E. Facile room temperature synthesis of fluorine-18 labeled fluoronicotinic acid-2,3,5,6-tetrafluorophenyl ester without azeotropic drying of fluorine-18. Nucl. Med. Biol. 2016, 43, 770-772. [CrossRef] [PubMed]

36. Basuli, F.; Zhang, X.; Woodroofe, C.C.; Jagoda, E.M.; Choyke, P.L.; Swenson, R.E. Fast indirect fluorine-18 labeling of protein/peptide using the useful 6-fluoronicotinic acid-2,3,5,6-tetrafluorophenyl prosthetic group: A method comparable to direct fluorination. J. Label. Compd. Radiopharm. 2017, 60, 168-175. [CrossRef]

37. Tsumoto, H.; Murata, C.; Miyata, N.; Taguchi, R.; Kohda, K. Preparation of deuterated methyl and dimethyl substituted nicotinoylating agents for derivatization of the N-terminal of protein. Chem. Pharm. Bull. 2003, 51, 1399-1401. [CrossRef]

38. Olberg, D.E.; Arukwe, J.M.; Grace, D.; Hjelstuen, O.K.; Solbakken, M.; Kindberg, G.M.; Cuthbertson, A. One Step Radiosynthesis of 6-[18F]Fluoronicotinic Acid 2,3,5,6-Tetrafluorophenyl Ester ([18F]F-Py-TFP): A New Prosthetic Group for Efficient Labeling of Biomolecules with Fluorine-18. J. Med. Chem. 2010, 53, 1732-1740. [CrossRef]

39. Mu, L.; Höhne, A.; Schubiger, P.A.; Ametamey, S.M.; Graham, K.; Cyr, J.E.; Dinkelborg, L.; Stellfeld, T.; Srinivasan, A.; Voigtmann, U.; et al. Silicon-Based Building Blocks for One-Step18F-Radiolabeling of Peptides for PET Imaging. Angew. Chem. Int. Ed. 2008, 47, 4922-4925. [CrossRef]

40. Roehn, U.; Becaud, J.; Mu, L.; Srinivasan, A.; Stellfeld, T.; Fitzner, A.; Graham, K.; Dinkelborg, L.; Schubiger, A.P.; Ametamey, S.M. Nucleophilic ring-opening of activated aziridines: A one-step method for labeling biomolecules with fluorine-18. J. Fluor. Chem. 2009, 130, 902-912. [CrossRef]

41. Becaud, J.; Mu, L.; Karramkam, M.; Schubiger, P.A.; Ametamey, S.M.; Graham, K.; Stellfeld, T.; Lehmann, L.; Borkowski, S.; Berndorff, D.; et al. Direct One-Step18F-Labeling of Peptides via Nucleophilic Aromatic Substitution. Bioconjugate Chem. 2009, 20, 2254-2261. [CrossRef]

42. Höhne, A.; Mu, L.; Honer, M.; Schubiger, P.A.; Ametamey, S.M.; Graham, K.; Stellfeld, T.; Borkowski, S.; Berndorff, D.; Klar, U.; et al. Synthesis,18F-Labeling, andin Vitroandin VivoStudies of Bombesin Peptides Modified with Silicon-Based Building Blocks. Bioconjugate Chem. 2008, 19, 1871-1879. [CrossRef] [PubMed]

43. Thonon, D.; Goblet, D.; Goukens, E.; Kaisin, G.; Paris, J.; Aerts, J.; Lignon, S.; Franci, X.; Hustinx, R.; Luxen, A. Fully Automated Preparation and Conjugation of N-Succinimidyl 4-[18F]Fluorobenzoate ([18F]SFB) with RGD Peptide Using a GE FASTlab ${ }^{\text {TM }}$ Synthesizer. Mol. Imaging Biol. 2011, 13, 1088-1095. [CrossRef] [PubMed]

44. Ackermann, U.; Plougastel, L.; Wichmann, C.; Goh, Y.W.; Yeoh, S.D.; Poniger, S.S.; Tochon-Danguy, H.J.; Scott, A.M. Fully automated synthesis and coupling of [18F]FBEM to glutathione using the iPHASE FlexLab module. J. Label. Compd. Radiopharm. 2014, 57, 115-120. [CrossRef] [PubMed] 
45. Valdivia, A.C.; Estrada, M.; Hadizad, T.; Stewart, D.J.; Beanlands, R.S.; DaSilva, J.N. A fast, simple, and reproducible automated synthesis of [18F]FPyKYNE-c(RGDyK) for $\alpha \mathrm{v} \beta 3$ receptor positron emission tomography imaging. J. Label. Compd. Radiopharm. 2011, 55, 57-60. [CrossRef]

46. Inkster, J.A.H.; Colin, D.J.; Seimbille, Y. A novel 2-cyanobenzothiazole-based 18 F prosthetic group for conjugation to 1,2-aminothiol-bearing targeting vectors. Org. Biomol. Chem. 2015, 13, 3667-3676. [CrossRef] [PubMed]

47. Davis, R.A.; Drake, C.; Ippisch, R.C.; Moore, M.; Sutcliffe, J.L. Fully automated peptide radiolabeling from [18F]fluoride. RSC Adv. 2019, 9, 8638-8649. [CrossRef]

48. Jacobson, O. PET imaging of CXCR4 using copper-64 labeled peptide antagonist. Theranostics 2011, 1, 251. [CrossRef]

49. Hanaoka, H.; Mukai, T.; Tamamura, H.; Mori, T.; Ishino, S.; Ogawa, K.; Iida, Y.; Doi, R.; Fujii, N.; Saji, H. Development of a 111In-labeled peptide derivative targeting a chemokine receptor, CXCR4, for imaging tumors. Nucl. Med. Biol. 2006, 33, 489-494. [CrossRef] [PubMed]

50. Hennrich, U.; Seyler, L.; Schäfer, M.; Bauder-Wüst, U.; Eisenhut, M.; Semmler, W.; Bäuerle, T. Synthesis and in vitro evaluation of 68Ga-DOTA-4-FBn-TN14003, a novel tracer for the imaging of CXCR4 expression. Bioorg. Med. Chem. 2012, 20, 1502-1510. [CrossRef]

51. Jacobson, O.; Weiss, I.D.; Szajek, L.P.; Niu, G.; Ma, Y.; Kiesewetter, D.O.; Peled, A.; Eden, H.S.; Farber, J.M.; Chen, X. Improvement of CXCR4 tracer specificity for PET imaging. J. Control. Release 2012, 157, $216-223$. [CrossRef]

52. Peng, S.-B.; Peek, V.; Zhai, Y.; Paul, D.C.; Lou, Q.; Xia, X.; Eessalu, T.; Kohn, W.; Tang, S. Akt activation, but not extracellular signal-regulated kinase activation, is required for SDF-1alpha/CXCR4-mediated migration of epitheloid carcinoma cells. Mol. Cancer Res. 2005, 3, 227-236. [CrossRef] [PubMed]

Sample Availability: Samples of the compounds are available from the authors.

(C) 2020 by the authors. Licensee MDPI, Basel, Switzerland. This article is an open access article distributed under the terms and conditions of the Creative Commons Attribution (CC BY) license (http://creativecommons.org/licenses/by/4.0/). 